\title{
DISCOURSE MODEL OF CHRISTIAN CANONICAL TEXTS VERBAL INFLUENCE
}

\section{Cholan V. Y., Ponomarova V. A.}

\section{INTRODUCTION}

It is well known that people are social beings, hence they are possessing a mind capable of abstract thinking and dreaming, and a language as a system of signs actualized in speech activity: a human being is formed and exists in its ecological niche only by informative interaction with other people and under their influence. Therefore, the fundamental directions of such a paradoxical multi-vector phenomenon as the verbal impact carried out in the communicative process with the help of certain types of texts on the individual and collective consciousness of the subject perceiving textual information are of constant interest to linguists.

From the point of view of R.M. Blakar, H. Weinrich, T.A. van Dyck, the verbal influence which is realized in the course of speech communication by the purposeful transfer of the addressed information through texts, which consists in the differentiated use of special language tools for the implementation of the ideologically oriented attitudes into the perceptual consciousness of an individual or group or the whole society. It is argued that the impact is an inherent property of any text, it is a text category, as each text communicates information essential to motivate the perceiver to perform certain mental and physical actions, taking a planned place in the activities of the authorizing text. ${ }^{1}$

Ultimately, the linguistic methods and means of verbal influence are perceived as tools for exercising power in society. ${ }^{2,3,4,5}$. And taking into consideration the linguistic-textual parameters of speech communication, we

${ }^{1}$ Меньшикова Е.В. Воздейственность как текстовая категория (на материале английского языка). Современные проблемы науки и образования. 2014. № 4.

${ }^{2}$ Блакар P.М. Язык как инструмент социальной власти. Язык и моделирование социального взаимодействия. Москва : Прогресс, 1987.

${ }^{3}$ Вайнрих Х. Лингвистика лжи [пер. с нем.]. Язык и моделирование социального взаимодействия. Москва : Прогресс, 1987.

${ }^{4}$ Дейк Т.А., ван. Дискурс и власть [пер. с нем.]. Москва : УРСС, 2013.

5 Дейк Т.А., ван. Язык. Познание. Коммуникация: сб. работ. Москва : Прогресс, 1989. $312 \mathrm{c}$. 
can talk about the systemic congruence of the communicative process and its verbal impact on its addressees as the content of this process ${ }^{6,7}$.

\section{Signs and symbols of text as units of verbal action}

Using the term "verbal influence" in relation to the purposeful mental and speech actions of the subject 1, authorizing the text addressed to the subject 2 which is the object of addressing (individual or collective), we essentially mean the result of this supernatural process, the change of consciousness of the subject 2 - the addressee. The paradox is in that the set of signs of the text perceived remotely, receptively (audibly) by the subjectrecipient, and ordered according to the laws of the corresponding language system established in the society and structured according to the parameters of its text genres, comes into contact with their mental structures and transforms consciousness.

One of the linguo-philosophical theses, belonging to the English scientist J. Fodor, explains the mechanism of verbal influence by the existence in each human individual of an innate language of thought, the mental language ("mentalism"), which is the basis of natural (national) language. The mental language is ontologically intended for the autocommunicative mentalintellectual activity of a person, that means that all sensations, memories, intentions of a person are framed in the form of semantic-syntactic constructions of this language ${ }^{8}$.

Textual utterances in the native language correspond to the sentences of the mental language, as having a similar grammatical structure, but different functions. consciousness, transforming it according to the vector of change provided by the addressee.

Thus, the real text sign, being an impulse for associative operations with the sign units of the mental lexicon and syntax, is inbuilt into the structures of In accordance with the linguistic-philosophical concepts known in linguistics, a textual (speech, linguistic) sign is understood as a bilateral material-ideal unit of the semiotic-linguistic system used in speech

6 Чолан В.Я. Джерела формування категоріальних ознак тексту у сфері військової україномовної комунікації. Мова і культура. (Науковий журнал). Вип. 11. Т. 9 (121). Київ : Видавничий дім Дмитра Бураго, 2009. С. 94-100.

7 Шевель С.М. До питання про таксономію комунікативних параметрів епістолярію. Філологічні науки: зб. наук. пр. Суми : Видавництво СДПУ імені А.С. Макаренка, 2009. С. 150-161.

${ }^{8}$ Философские теории / [пер. с англ. А, Карнаушко; науч. ред. Н. Волков; под ред. Барри Лёвер; вступ. ст. Стивенс Лоу]. Москва : РИПОЛ классик, 2017. 160 с.; илл. С. 60. 
communication intended for naming an abstract (abstract) symbolic meaning.

The ideal sign substance is materialized by the sound-letter form, rigidly connected with the internal composition (meaning), and it is this connection that is fixed by the collective consciousness of society and the individual united by a common language system. So the transformational possibilities in relation to the structures of human consciousness, characterizing the inseparable unity of both planes of the sign perceived by the addressee, are realized in the process of verbal influence, which G.G. Pocheptsov and R.H. Thaler define as "architecture of choice", meaning the addressee's choice impactful contact with text signs - symbols. After all, the linguistic term sign, which has Indo-European origin, semantically correlates with the Greek

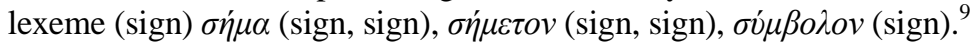

The identity between a sign and a symbol, which is important for the study of the specifics of the verbal influence, is substantiated in the works of A.F. Losev, who argues that the acts of consciousness necessary for designation and symbolization cannot be considered separately, but, on the contrary, taken separately, does not absolutely refer to the sign or symbol itself. The symbol of a phenomenon, a person, a thing - an object, or an object to which attention is directed - is the internal-external expressive structure of a thing, as well as a sign, which in its immediate content has no connection with the signified content. Consequently, a symbol is a sign, since all the properties of a sign are inherent in it. ${ }^{10}$

Clarifying the differences between a symbol and a sign, E.A. Selivanova notes that the symbol belongs to a different conceptual sphere, paying attention to its secondary structural and conceptual nature of the sign.

Based on the symbolic character of a text unit, a symbol represents one of the signs in its organization. However, if we consider the formal-syntactic plan of a text unit, it should be noted that the structural component correlated with the symbol does not occupy a predicative position, but expressing the general idea of an eventful nature, embodies a certain situation. The symbol is deictic, not attributive ${ }^{11}$.

From the point of view of Yu. Lotman, a symbol by its nature is simultaneously located in the coordinates of the horizontal plane of

9 Почепцов Г.Г. Пропаганда 2. 0. ; художник-оформитель М.С. Мендор. Харьков: Фолио, 2018. 796 с. C. 239-240, 247; Thaler R.H., Sunstein C.R. Nudge. Improving decisions about health, wealth, and happiness. New-York, 2009. 359 p.

10 Лосев А.Ф. Проблема символа и реалистическое искусство. Изд. второе, исправленное. Москва : Искусство, 1995. 320 с. С. 113.

${ }^{11}$ Селіванова О.О. Сучасна лінгвістика: термінологічна енциклопедія. Полтава : Довкілля-К. 2006. 716 с. С. 535-536. 
semantics and the vertical one of the background knowledge. Scientists emphasize that the symbol does not belong to one synchronic section of linguoculture, but vertically permeates all layers of the culture of an ethnic group according to the vector "from the past to the future", leading to its original source ${ }^{12}$.

It is this infinite semantic perspective that is the most important condition for the functioning of the symbol; the loss of this perspective leads to the destruction of the symbol.

Consequently, a linguistic unit representing a symbol in a textual structure must have a deep (long-standing) etymological history, leading to the original meaning of this unit.

The specificity of the verbal impact of symbols included in the text architectonics is due to several factors:

- the symbol is relevant only for the cultural and ethnic community, the elite of "friends" and serves as a way of uniting them. This is the manifestation of the communicative and pragmatic functional purpose of the symbol;

- the meaning of the symbol is stored ready-made in the collective consciousness of the linguocultural group, ethnos, and represents the semantic core of linguocultural constants.

If in the historical typology the term constant implies a constant value in a series of changing (variable) values, which does not change its values within the conditions of the set communication tasks, then in our work the concept of a linguocultural constant is interpreted basing on the research of Yu.S. Stepanov and F.S. Batsevich ${ }^{13}$.

First of all, the linguocultural constant is viewed as a means of verbal influence in the form of a linguistic sign - a symbol that represents the meaning of ideological information that is valuable for an ethnos. It can be taken into consideration that linguocultural constants are endowed with the most powerful potential for influencing the addressee of the text, since they verbalize the most important moral and linguistic values of the ethnos related to the stratification of the 'good' and 'evil', fixed in relatively stable conceptual structures of the collective ethnic consciousness.

According to M. M. Bakhtin, the main in the ethnic fund of moral and linguistic values, which represent the worldview guidelines of the society,

${ }^{12}$ Ю.М. Лотман и тартусско-московская семиотическая школа. Москва : Гнозис, 1994. 560 с. Серия «Язык. Семиотика. Культура»]. 612 с. С. №; №*, 84-89.

13 Степанов Ю.С. Константы. Словарь русской культуры. Опыт исследования. 2013. 
are the linguocultural constants of TRUTH, TRUTH, GOOD, BEAUTY, HISTORY ${ }^{14}$.

Linguocultural constants are characterized by the constant, over a long historical time, use in texts, significant for the culture of a certain ethnic (national) community, the totality of which determines the type of ethnos culture (in the broad interpretation of this term) and the type of the discourse where the text functions. As F.S.Batsevich emphasized, the constants are embedded in every idioethnic system of the language, their existence is supported by the language and is preserved in it $^{15}$.

Determining the features of the verbal influence inherent in signs symbols in the text, presented either as structural components of a structure or as an independent sentence of a certain type, we should set the parameters of these sign units:

- primordial or borrowed character of its origin;

- data on text monuments in which the symbolic unit is found;

- the form and meaning of a sign unit in text monuments (in particular, in its graphic versions; if a sign is a lexical unit, then as a structurally independent one or in the structural composition of a complex word);

- representation of the sign unit in the Indo-European linguistic area: a) taking into account the structure of the Indo-European root (the connection with the Indo-European root is extremely important); b) taking into account the connection with ancient symbols, ancient cultural and historical symbols (preformants, taboo negation, metathesis);

- establishment of the original form and initial meaning, a historical process, the chronology of changes in form and meaning (archetype, etymon), depending on the linguistic factors (the phonetic and semantic linguistic laws) and non-linguistic factors (such as living conditions, territorial distribution of speakers of a given language, ethnic collective mentality);

- identifying cases when lexical sign units, synonymous with the selected one, reveal a common line of semantic development in closely related and non-closely related Indo-European languages, similar to that

14 Бахтин М.М. Проблема текста в лингвистике, филологии и других гуманитарных науках. Опыт философского анализа. / Литературно-критические статьи. / Сост. С. Бочаров и В. Кожинов. Москва : Художественная литература, 1986. 543 c. С. $473,475-500$.

15 Бацевич Ф.С. Словник термінів міжкультурної комунікації. Київ : Довіра, 2007. 205 с. (Словники України. Довідкове видання). С. 86, 87. 
inherent in the selected sign unit. You can deduce certain semantic laws (lexical and semantic parallels) ${ }^{16}$.

We would like to emphasize that in our study, the interpretation of a text sign is based on the concept of a text formulated in the works of E.A. Selivanova as a sign integrity of the dialogical nature, conceptually and structurally embedded in the linguo-psychological structures of the communicants' consciousness, due to which it serves as a pragmatic mediator between them and the semiotic universe of culture ${ }^{17}$.

Emphasizing that each text is based on the synthesis of generally understandable and conventional systems of linguistic signs within a certain society, M.M. Bakhtin singles out two so-called poles in the organization of text structures as a consequence of this synthesis ${ }^{18}$.

Obviously, the scientist's understanding of the poles implies the centers of text signs, represented by communicative means originating from the fund of a certain language system and ways of forming the expressive possibilities of text units, actualized in the structuring of a specific text, which, in our opinion, provide its universal and differential (identification) categorical features, inherent in individual structural compound text. About the degree of influence of the usual structural units of the text ${ }^{19}$.

One conditional pole is formed by linguistic methods and means regularly repeated and reproduced in each text sequences (combinations) of sign elements of the native language system with nuclear definitive meanings, which constitute the basis of universal (categorical) text signs.

On this basis, universal categorical textual features are considered as a generalization of the characteristics of different dimensions of the text structure in their ratios characteristic of the entire set or the absolute majority of the studied texts (speech text units of a certain system class). Universal categorical textual features, which are most essential in the subsystem of a given text (text corpus) for understanding text architectonics, are extrapolated to the principles of constructing statements that are normative for the linguistic system. The obligatory nature of these characteristics of the

16 Макаев Э.А. Реконструкция индоевропейского этимона. Bonpocbl языкознания. 1967. № 4. С. 6-7.

${ }^{17}$ Селіванова О.О. Сучасна лінгвістика: термінологічна енциклопедія. Полтава : Довкілля-К. 2006. С. 599-600.

18 Бахтин М.М. Проблема текста в лингвистике, филологии и других гуманитарных науках. Опыт философского анализа. Литературно-критические статьи. Сост. С. Бочаров и В. Кожинов. Москва : Художественная литература, 1986. 543 c. C. $473-500$. C. 475

${ }^{19}$ Категорія темпоральності у синтаксичній структурі текстів. Культура народов Причерноморья. 2010. Т. 2, № 185. С. 352-354. 
meaningful, formal, functional plans of the structure of a textual structure, which determine its communicative-pragmatic status, just makes them universal.

\section{Linguocultural constants as a tool of verbal influence}

The sign-linguistic manifestation of universal categorical textual features is based on constructions, structurally organized in accordance with the grammatical tradition that has developed within a given language system, which contains signs - symbols, but does not contain constants as components of their structure ${ }^{20}$.

In support of the thesis that such textual constructions realize the meaning of textual categories in traditional ways and means, we can give an example of representing the textual category of personality using pronominal deixis units, whose meanings and arrangement of structural positions in a sentence reflect the status asymmetry of propositional (real) positions of subjects named by pronouns.

At the same time, the secondary conditional pole of each text concentrates the usual or conventional (original) linguistic ways and means of representing differential (identificational) text categorical features, which we define as latent linguistic (formal-structural, semantic-syntactic, communicativepragmatic) characteristics of the architectonics of the studied texts.

The originality of the conventional linguistic methods and means of representing the categorical features of a text is based on the constructions that, first, contain structural components that represent linguocultural constants; second, in the traditional grammar they represent peripheral for expressing categorical meanings types of the sentences. However, in a discourse that is identical to the communicative area of the functioning of texts, it is the usual / conventional linguistic methods and means of expressing the categorical features of the text that most accurately identify the selected text corpus, pointing to the determinism of the architectonic structure of text units by the conditions of verbal communication in a certain sphere of the life of society. Consequently, in the corresponding discourse, textual constructions or carriers of linguocultural constants, constitute the core, the main toolkit of the verbal influence.

In particular, Church Slavonic Statutory, or Typical texts are characterized by the frequent usage as a differential means of expressing a textual categorical attribute of temporality of structures with a linguocultural constant represented by the adverb ДНЕСЬ, which has the lexical meaning

20 Чолан В.Я. Синтаксис українських офіційно-ділових текстів у військовій сфері : автореф. ...канд. дис.... Київ, 2011, 20 с. С. 6. 
of the actual present tense, in combination with the present tense verb of an imperfect form to denote long-standing (past) actions, phenomena, processes.

For example, in the texts of the Lenten Triod: «ДНЕСЬ Христу ЯВЛЯЕТСЯ об одну страну Иордана ходящу, болезнь Лазарева...»; «ДНЕСЬ Лазарь умерый ПОГРЕБАЕТСЯ и рыдания ПОЮТ его сроднииь...»; «Дводенствует ДНЕСь Лазарь умерый...»;

in the text of the Canon for Christmas: «Дева ДНЕСЬ Пресущетвенного РАЖДАЕТ и земля вертеп Неприступному ПРИНОСИТ, ангели с пастырьми СЛАВОСЛОВЯТ, волсви же со звездою ПЕШЕШЕСТВУЮТ, нас бо ради родися Отроча Младо Превечный Бог». ("The Virgin GIVES THE DAY of the Most Sacred, and the earth BRINGS the nativity scene to the Unapproachable, the angels and the shepherds HAVE WALKED, and WALKING with the star, we are for the sake of the birth of the Otroch Young Eternal God.").

In the sign-linguistic structural complex "adverb + verb", the attention is drawn to the position of the present tense verb of the imperfect form, traditionally denoting repeated regular actions with an unattainable result. In the structure of the given textual constructions, this verb form is used to designate a once-occurred productive event of a long past tense, thereby providing here a semantic and grammatical transformation of categorical meanings of time, which implies both the actualization of reference events and a pattern of reaction to them that has no options, common to the society to which the texts are addressed.

In the scientific literature, such a linguistic phenomenon of persistent temporal correlation of past or future textual actions, states, processes with the meanings of the syntactic present tense is called the effect of the "presence of the absent" 21 .

This phenomenon is justified in this way. The performance of actions to which the addressee prompts (compels) the collective addresser is possible only under the condition of maximum consolidation of the collective, when people come together and, overcoming their natural separation and isolation, react as one body, as a single personality to the needs of the communicative situation of the incentive and regulatory influence. According to our observations, this is a phenomenon of prescriptive communication that distinguishes the liturgical and military spheres, where a collective that characterizes the merging of many individuals into a monolithic community reacts to prescriptive texts by performing the necessary actions as one person.

21 Шмеман. А. протопресвитер. Великий Пост / Сост. С.А. Шмемана. Пер. с англ. С. Осоргиной. Москва : Московский рабочий, 1993. 111 с. С. 76-80. 
At the same time, the assignment of the objective time of an action, which should take place or partially took place, into the plane of the syntactic present tense, makes it possible to combine in the structural basis of the text and the event associated with a specific situation of motivation (compulsion), and, most importantly, a general, conciliar reaction to it.

Thus, it is possible to overcome the natural individualism of the verbal action and achieve the special unity of its members inherent only in this collective, which is necessary for its successful activity. This method of verbal influence, called in French psycholinguistics the term "proactive transfer", is focused on the use of skills, abilities, knowledge acquired in a specific situation in situations that differ from the initial type, where they were originally formed ${ }^{22}$.

The linguocultural Church Slavonic constant ДНЕСЬ transforms the understanding of discrete-time in the collective consciousness of the Slavic ethnos, symbolizing the statement of an event that is not limited by a time frame.

\section{Functional Purpose of Christian Canonical Statutory Texts}

After all, the universalist ideology of the sacred-political statehood, inherited from the Byzantine Empire, formalized and presented by the methods and means of the translated Church Slavonic canonical Christian texts, was creatively perceived, interpreted by the addressee - the society of the Kievan Rus state of the tenth century in the model of hierarchical institutions of church and state, providing for the assimilation relevant legal, military, cultural, educational, financial-economic, moral-ethical and contractual norms, fixed by written texts of laws, decrees, statutes, in interaction with the arrangement of traditions and customs. This ideology determined the status asymmetric hierarchical organization of the main state spheres of communicative activity of the society of Kievan Rus for the conciliar-one-origin principle, which became the guiding principle for the formation of a new worldview of a super-ethnos of a new type.

Thus, in particular, the varieties of the prescriptive textual constructions of the Book of Proverbs, which are the part of Christian canonical texts, are a verbal way of reflecting the Christianized social consciousness of the early Middle Ages, which contrasted real disorder with speculative order, the essence of which is expressed by the ancient Greek speech formula $\eta \dot{\gamma} \tau \dot{\alpha} \xi 1 \zeta$, ordo - a categorical idea of order, the will to order as an ontological, ethical and aesthetic postulate. Formal and semantic structural plans of varieties of

22 Экспериментальная психология. Вып. IV. [Ред. сост. Поль Фресс и Жан Пиаже. Общая ред. и предисловие действительного члена Академии пед. наук А. Н. Леонтьева]. Пер. с французского. Москва : Прогресс, 1973. 344 с. С. 7-8. 
textual prescriptive constructions contain tokens denoting linguistic and cultural constants (basic concepts), fixed in the structures of ethnic consciousness by ancient sacred images - symbols. For example, a textual construction, classified as a formal-semantic category of imperatives, with the linguistic and cultural constant "neighbors":

«НЕ ОТКАЗЫВАЙ в благодеянии НУЖДАЮЩЕМУСЯ, когда рука твоя в силе сделать его. НЕ ЗАМЫШЛЯЙ против БЛИЖНЕГО твого зла, когда он не сделал зла тебе»: ("DO NOT REFUSE beneficence to the PERSON IN NEED when your hand is able to do it. DO NOT invent something evil against your NEAREST when he has not done evil to you");

the text construction for a series of conventional imperatives with the linguocultural constant "justice”: «ВЕРНЫЙ СВИДЕТЕЛЬ не лжёт, а НЕВЕРНЫЙ СВИДЕТЕЛЬ наговорит много лжси»; «НЕВЕРНЫЕ ВЕСЫ - МЕРЗОСТЬ пред Господом, но ПРАВИЛЬНЫЙ ВЕС - УГОДЕН Ему»: ("A FAITHFUL WITNESS does not lie, and an UNFAITHFUL WITNESS will tell a lot of lies"; "THE WRONG WEIGHT IS ABOMINATION before the Lord, but THE RIGHT WEIGHT IS PLEASANT to Him ");

he text construction of the category of conventional imperatives with the linguistic and cultural constant "state": «Во МНОЖЕСТВЕ НАРОДА ВЕЛИЧИЕ ЦАРЯ, а при малолюдстве народа беда государю»: (“IN A LOT OF PEOPLE IS THE GREATNESS OF THE KING, and with the small population, trouble for the sovereign") $)^{23}$.

It should be added that the vector, aimed at the all-encompassing order as a constant of the early medieval state-building process in the genogeographical space of the Kyivan Rus state, is consciously set by the collective addressee of the corpus of Christian canonical texts and consciously perceived by the collective addressee of these texts, ethnically heterogeneous society, represented by textual constructions marked by the symmetry of the structural positions of certain lexical components.

It is important for structuring texts with the function of verbal control the inseparable connection of the textual function of verbal control with such a logical and psychological category as will. The meaning of this category in the parameters of managerial communication in state-building spheres (including professional fields), we substantiate taking into account the direct, vocabulary understanding of the term "will" as a set of verbal ways to exercise the right to dispose, make decisions with knowledge of the case,

${ }^{23}$ Ветхий Завет. Книга Притч. Москва : Российское библейское общество, 1998. 1008 c. C. $604,605-606$. 
directing the actions of the object of volitional influence to a pre-planned goal $^{24,25}$.

In our opinion, the obligatory presence of a volitional component in the objective intentions of the communicants of the Slavic Liturgical Discourse determines the peculiarities of the formal-semantic structure of the varieties of textual imperatives. In particular, we associate the regulation of the spectrum of graduated modal meanings of textual units with the voluntaristic intention of the addressees of Church Slavonic canonical Christian texts, understanding this phenomenon as a result of a specific synergy of linguistic-semiotic systems (subsystems) that characterizes the corpus of analyzed texts.

Based on the fact that the extralingual concept of management is systemic in nature, we consider it as a way to realize the content of communication that is the verbal influence and achieve the goal of communication. This method involves the targeted influence of one system link, the control, which should be understood as the endowed addressee of the text (= subject of management), the other, managed, which means a well-organized community (addressee of the text $=$ object of management), is realized through texts as the main verbal mechanism of the communicative process. According to the theories of IP Susov and OO Leontiev, managerial actions are embodied in typical textual forms, correlated with the forms of the addressee's vision of a fragment of reality relevant to him in these conditions of typical communicative situations, currently determining the forms of relevant acts of predication as a connection of a predicative feature with its carrier. ${ }^{26}$

A similar interpretation of the essence of verbal management in professional fields is found in G.V. Kolshansky, who identified this process with the task of the addressee of the text through the establishment of links between objects, actions, phenomena, events used as an object of information (act of predication), to convey to the addressee his knowledge of the subject (cognitive act), with motivation aimed at motivating him to

24 Белолипецкий В.К. Этика и культура управления : [учеб.-практ. пос.] / В.К. Белолипецкий, Л.Г. Павлова. Москва : ИКЦ «МарТ» ; Ростов-на-Дону : Издательский центр МарТ, 2004. 384 с. (Серия «Учебный курс»). С. 54-79.

25 Литвиненко О.В. Управління системами формування суспільної свідомості в кризових ситуаціях. Тези виступів на міжнародному семінарі «Інформація з питань міжнародних відносин та політики безпеки: проблеми і можливості для неурядових організацій в Україні». Київ : 1997. С. 13-19.

26 Леонтьев А.А. Высказывание как предмет лингвистики, психолингвистики и теории коммуникации. Синтаксис текста : сб. науч. тр. [Текст, его проблемы и категории]. Москва : Наука, 1979. 368 с. С. 18-36. 
specific actions (intellectual or material) ${ }^{27}$. Hence the conclusion that the communicative scheme of verbal control in the Slavic Liturgical Discourse presupposes the interaction of status-unequal addressees and addressees, based on the asymmetry of their real positions.

The parameters of status asymmetry, characteristic of the communicative scheme of verbal control in the Slavic Liturgical Discourse, determine the type of subject-object relations between the structural positions of textual components, on which the status positions of real communicators are indirectly projected.

It is necessary to emphasize the importance of subject-object relations for understanding the verbal influence - the content of communication and the communicative function of management, inherent in the Church Slavonic canonical Christian texts of the Liturgical Discourse. Since this type of relationship between the positions of communicative subjects, formalized in the structure of different textual units of Slavic Liturgical Discourse with a limited number of types of sentences, illustrates the status distance between real communicators, we consider it as an important specific parameter of discursive communication.

\section{The Model of the verbal impact in text communication}

We consider a unique type of the verbal impact on the collective consciousness of the communicative subject - the society of the early medieval state of Kievan Rus carried out in the process of communication using the structures of the Statutory / Typical texts containing linguocultural constants, represented by the sign units of the Church Slavonic linguisticsemiotic system, based on the figurative-conceptual model with feedback.

The Pre-action - the transformation of information in the mind of A1 the addressee (external environment), into what A2 should perceive - the addressee $=$ the internal system adjusts to something external.

In the consciousness of $\mathrm{A} 1$ - the addressee happens:

1. 1. in the internal mental-semiotic environment $(\mathrm{Sg} 2-\mathrm{Sg} 2)$ of the $\mathrm{A} 1$ subsystem - the addressee, or in the internal environment of the mentalsemiotic space, there is a two-phase transformation of the text, or textual representation of information (images), into what A2 - the addressee should perceive:

- initial formation of structural and semantic schemes of text units as a textual representation of information (verbalized images);

27 Колшанский Г.В. Коммуникативная функция и структура языка. [Изд. 3-е]. Москва : Издательство ЛКИ, 2007. 176 с. Лингвистическое наследие ХХ века. С. 60-65 
- the verbalized images formed in the linguistic consciousness of the addressee are oriented towards the perceiving mental-semiotic subsystem $\mathrm{A} 2$ - the addressee $(\mathrm{Sg} 2-\mathrm{Sg} 2)$ : the addressee adjusts to the external subsystem of the addressee;

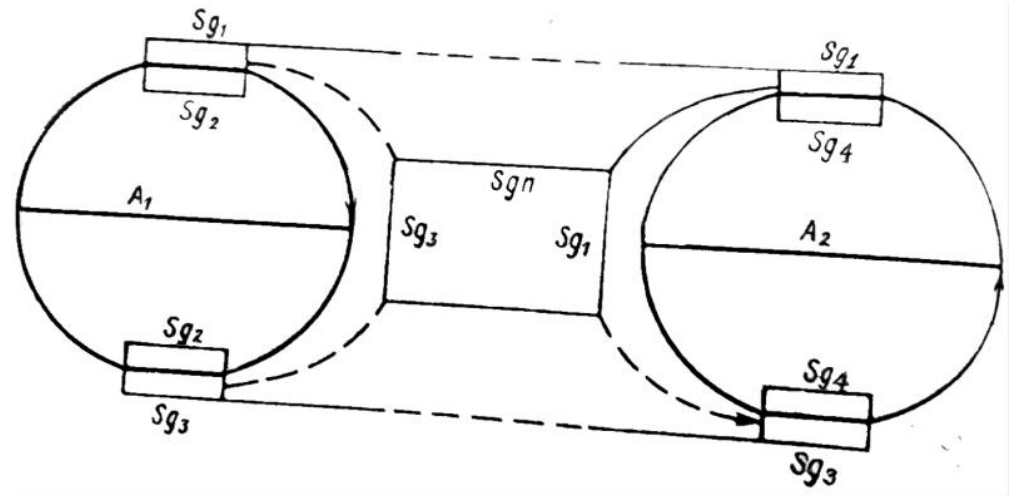

Fig. 1. A unique type of the verbal impact on the collective consciousness of the early medieval state of Kievan Rus

1. 2. at this stage, the $\mathrm{Sg} 1$ (segment of the intermediate environment) of the addressee affects the $\mathrm{Sg} 2$ (segment of the internal environment) of the addressee: the addressee 1 rethinks and improves the textual formulations of verbalized images for himself too.

$\mathrm{Sg} 2$ - internal environment: preparation of the original wording. Original wording

$\mathrm{Sg} 1$ - intermediate environment: the final formulation of textual information for external A2 - addressee

$\mathrm{Sg} 1$ - affects Sg2 A1 - addressee

Sg1 A1 - addressee - transfer of information to external A2 - addressee

$\mathrm{Sg} 4$ - comprehension of the meaning by participant A2 - addressee

$\mathrm{Sg} 4$ - goes to $\mathrm{Sg} 3$ (intermediate environment for $\mathrm{A} 2$ - addressee)

$\mathrm{Sg} 3$ - addressee - returns to the speech of $\mathrm{A} 1$ - addressee

$\mathrm{Sg} 3 \mathrm{~A} 2$ - the addressee interacts with Sg2 A1 - the addressee (Fig. 1).

The model of verbal influence in isocultural intersystem discourse is a systemic correlation of certain components that mediate information exchange and communicative actions, as well as the ratio of certain operations, the result of which is the transfer of information from the source the addressee through its text to the recipient - the addressee. 
As established by studies of the nature of semiotic structures, the complexity of the structure is in direct proportion to the complexity of the transmitted information. The complication of the nature of information inevitably leads to the complication of the linguistic-semiotic system used for its transmission or the interacting linguistic-semiotic systems used. In our study, we use a balanced synergy of subsystems that completely transmit a certain unified volume of information, taking into account the overcoming of noise in communication channels, where unnecessary complexity is eliminated, which makes it possible to achieve the adequacy of the planned communication goal in discourse.

\section{CONCLUSIONS}

The multi-aspect linguistic phenomenon of verbal impact on the individual and collective consciousness of the subject, perceiving textual information, constitutes the content of the communication process. Verbal influence is carried out through the purposeful transmission of addressed information through texts, whose immanent property - impact - is interpreted as a universal text category. The textual category of impact concentrates differentiated linguistic methods and means, endowed with the potential of introducing ideologically marked attitudes into the perceiving consciousness of an individual or a collective, society, for the implementation of certain mental and physical actions planned by the addressee of the text.

The algorithm of verbal influence is carried out due to the interconnections of the correlating triad: the object of designation denoting a linguistic (speech) sign - a symbol, the sound-letter form of which is assigned to its meaning, and the image they cause, correlated with the image that constantly exists in the mental segments of the collective and individual ethnic consciousness in forms of mental language units.

Textual means of verbal influence are polarized. According to their expressive capabilities, they represent the universal and differential categorical characteristics of the text.

The originality of linguistic methods and means of representing the differential categorical features of the text is based on constructions that contain structural components that represent linguocultural constants. In traditional grammar, these means are types of sentences peripheral for expressing categorical meanings. However, in a discourse that is identical to the communicative space of the functioning of texts, it is the usual linguistic methods and means of expressing the categorical features of the text that most accurately identify the selected text corpus, pointing to the determinism of the architectonic structure of text units by the conditions of verbal communication in a certain sphere of the life of society. 
Linguocultural constants, represented by the sign units of the Church Slavonic linguistic-semiotic system, act as specific carriers of verbal impact, carried out on the basis of a figurative-conceptual model with feedback in isocultural intersystem discourse.

\section{SUMMARY}

The section proposes and substantiates a figurative-conceptual model of the implementation of the content of the communicative process - verbal impact on the collective consciousness of the communicative subject society.

The phenomenal psycholinguistic type of the investigated verbal impact, formed in the linguogenogeographic space of the early medieval state of Kievan Rus, is carried out in an isocultural intersystem discourse due to the functioning of translated Church Slavonic Christian canonical texts.

The model manifests an algorithm of verbal influence, which provides for the correlation with the targets of the influence of the linguistic-mental environments of both communicators, and the addressee and addressee of the texts. Text dominant constructions, represented by semantic and syntactic varieties of sign units of the Church Slavonic linguistic-semiotic system, containing the structural positions of linguocultural constants, are presented as the main nuclear tools of verbal influence. Thou, algorithm of verbal influence is carried out due to the interconnections of the correlating triad: the object of designation denoting a linguistic (speech) sign - a symbol, the sound-letter form of which is assigned to its meaning, and the image they cause, correlated with the image that constantly exists in the mental segments of the collective and individual ethnic consciousness in forms of mental language units.

\section{REFERENCES}

1. Бацевич Ф.С. Словник термінів міжкультурної комунікації. Київ : Довіра, 2007. 205 с. (Словники України. Довідкове видання).

2. Белолипецкий В.К. Этика и культура управления : [учеб.-практ. пос.] / В.К. Белолипецкий, Л.Г. Павлова. Москва : ИКЦ «МарТ»; Ростов-на-Дону : Издательский центр МарТ, 2004.84 с. (Серия «Учебный курс»).

3. Блакар Р.М. Язык как инструмент социальной власти. Язык и моделирование социального взаимодействия. Москва : Прогресс, 1987.

4. Вайнрих X. Лингвистика лжи [пер. с нем.]. Язык и моделирование социального взаимодействия. Москва : Прогресс, 1987.

5. Ветхий Завет. Книга Притч. Москва : Российское библейское общество, 1998. 1008 с. 
6. Дейк Т.А., ван. Дискурс и власть [пер. с нем.]. Москва : УРСС, 2013.

7. Дейк Т.А., ван. Язык. Познание. Коммуникация: сб. работ. Москва : Прогресс, 1989. 312 с.

8. Колшанский Г.В. Коммуникативная функция и структура языка. [Изд. 3-е]. Москва : Издательство ЛКИ, 2007. 176 с. (Лингвистическое наследие XX века).

9. Левицкий Ю.А. Лингвистика текста: [учеб. пособие]. Москва : Высшая школа, 2006. 207 с.

10. Леонтьев А.А. Высказывание как предмет лингвистики, психолингвистики и теории коммуникации. Синтаксис текста: сб. науч. тр. [Текст, его проблемы и категории]. Москва : Наука, 1979. 368 с.

11. Литвиненко О.В. Управління системами формування суспільної свідомості в кризових ситуаціях. Тези виступів на міжнародному семінарі «Інформачія з питань міжнародних відносин та політики безпеки: проблеми і можливості для неурядових організацій в Україні». Київ : 1997. С. 13-19.

12. Лосев А.Ф. Проблема символа и реалистическое искусство. Изд. второе, исправленное. Москва : Искусство, 1995. 320 с.

13. Ю.М. Лотман и тартусско-московская семиотическая школа. Москва : Гнозис, 1994. 560 с. Серия «Язык. Семиотика. Культура». 612 с.

14. Макаев Э.А. Реконструкция индоевропейского этимона. Вопросы языкознания. 1967. № 4. С. 6-7.

15. Меньшикова Е.В. «Воздейственность» как текстовая категория (на материале английского языка). Современные проблемы науки $и$ образования. 2014. № 4. С. 23-29.

16. Почепцов Г.Г. Пропаганда 2. 0. / Георгий Почепцов; художникоформитель М.С. Мендор. Харьков : Фолио, 2018.796 с.

17. Селіванова О.О. Сучасна лінгвістика: термінологічна енциклопедія. Полтава : Довкілля-К. 2006. 716 с.

18. Философские теории / [пер. с англ. А. Карнаушко; науч. ред. Н. Волков; под ред. Барри Лёвер; вступ. ст. Стивенс Лоу]. Москва : РИПОЛ классик, 2017. 160 с.; илл.

19. Чолан В.Я. Категорія темпоральності у синтаксичній структурі текстів. Культура народов Причерноморья. 2010. Т. 2, № 185. C. $352-354$.

20. Чолан В.Я. Синтаксис українських офіційно-ділових текстів у військовій сфері : автореф. ... канд. дис ... Київ, 2011, 20 с.

21. Шевель С.М. До питання про таксономію комунікативних параметрів епістолярію. Філологічні науки: зб. наук. пр. Суми : Видавництво СДПУ імені А.С. Макаренка, 2009. С. 150-161. 
22. Шмеман. А. протопресвитер. Великий Пост / Сост. С.А. Шмемана. Пер. с англ. С. Осоргиной. Москва : Московский рабочий, 1993. $111 \mathrm{c.}$

23. Экспериментальная психология. Вып. IV. [Ред.-сост. Поль Фресс и Жан Пиаже. Общая ред. и предисловие действительного члена Академии пед. наук А. Н. Леонтьева]. / Пер. с французского. Москва : Прогресс, 1973. 344 c.

24. Thaler R. H. Sunstein C. R. Nudge. Improving decisions about health, wealth, and happiness. New-York, 2009. 359 p.

Information about the authors: Cholan V. Y., orcid.org/0000-0001-5329-1604 Candidate of Philological Sciences, Doctoral Candidate Taras Shevchenko National University of Kyiv 60, Volodymyrska str., Kyiv, 01033, Ukraine

Ponomarova V. A., orcid.org/0000-0003-1880-4691, Scopus Author ID: 57218775973

Candidate of Pedagogical Sciences, Associate Professor at the Department of Methods of Teaching Ukrainian and Foreign Languages and Literatures Taras Shevchenko National University of Kyiv 60, Volodymyrska str., Kyiv, 01033, Ukraine 